\title{
POMOLOGICAL CHARACTERISTICS OF SOME APRICOT VARIETIES GROWN IN THE NORTHEAST AREA OF ROMANIA
}

\author{
Sorina Sîrbu ${ }^{1}$, Mădălina Iuliana Gherghel ${ }^{1 *}$, Elena Iurea ${ }^{1}$, Margareta Corneanu $^{1}$, \\ Simona Mihaela Chelaru ${ }^{1}$
}

${ }^{1}$ Research Station for Fruit-Growing, str. Ion Vodă cel Viteaz, nr. 3, Miroslava, Iaşi, Romania

\section{Current Trends in}

Natural Sciences

\begin{abstract}
The aim of this paper was to evaluated of some apricot genotypes grown in the Romanian North Eastern area conditions. During 2016-2018 studies were done at seven apricot cultivars ('Mamaia', 'Ovidiu', 'Fortuna', 'Amiral', 'Goldrich', 'Traian' and 'Dacia') which were in the experimental plot at RSFG Iassi, Romania. Number of days and sum of the active temperature from swelling buds (51 BBCH stage) to the beginning of blooming (61 BBCH stage), trunk section area of the tree and also fruit's weight were evaluated. Fruit weight of 'Dacia' registered $89.3 \mathrm{~g}$ but at 'Amiral' were $75.3 \mathrm{~g}$ as average for three years, but statistically there were no significant differences from the average. Regarding the period from the swelling of buds to blooming, the shortest period was of 10 days for the 'Dacia' and 'Traian' and the longest period was 14 days for the 'Ovidiu'. The sum of the active temperatures above the biological limit has varied according to the climatic conditions of the studied years from $103^{\circ} \mathrm{C}$ to the 'Dacia' and 'Traian' to $136^{\circ} \mathrm{C}$ for the 'Ovidiu'.
\end{abstract}

Keywords: apricot, assortment, cultivars, fruit, quality.

\section{INTRODUCTION}

Apricot - Armeniaca vulgaris Lam. (sin. Prunus armeniaca L.) is part of the Rosales Order, Rosaceae Family, Prunoideae Subfamily (Sîrbu and Paraschiv, 2005). Apricot tree species is widespread in the northern hemisphere, namely in Europe, Asia, America and Oceania (Militaru et al., 2015). In Romania, the area occupied by this fruit tree species in 2017 was 2,110 ha with a total production of 33,851 tons of which 3,563 tons were obtained in the N-E area of the country (according to faostat.org). Apricot fruits is a highly appreciated species for savory and scented fruits used for fresh consumption or for processing as compote, jam, juice, nectar, liqueurs, etc. (Corneanu and Corneanu, 2003). Apricot tree growing is difficult because it is a pretentious species of climate and soil, in addition it is affected by an incompletely known disease named premature ruin (Berar, 2002). The rich chemical composition of fruits also gives them the value of medicine and can be consumed in cases of physical and intellectual asthenia, anemia, insomnia or convalescence (Cociu, 1990; Cociu, 1993). Apricot kernels are very rich in nutrients, containing $29.5-57.7 \%$ fat, $28 \%$ pectic substances and $3.1 \%$ mineral salts (Grădinariu, 2002) and are used in 
confectionery, along with almonds or in industry, as a raw material for the extraction of industrial oils (Bălan, 2008). In the present paper we have analyzed the climate conditions, the vigor of the tree and the fruit mass for seven apricot cultivars in the period 2016-2018, from the Northeast area of Romania.

\section{MATERIALS AND METHODS}

The biological material on which the studies on the achievement of the objectives were performed in the demonstrative plot existing at RSFG Iasi in a total area of $0.5 \mathrm{ha}$; the trees are in the $11^{\text {th }}$ year of planting and were planted at a $4 \times 4 \mathrm{~m}$ distance, trees crown-shaped as palmette, without a support, irrigation or anti-hail system. The land is easily inclined from Northwest to Southeast, with a 5\% average slope, the altitude being $165 \mathrm{~m}$. The soil was on chernozem, eroded, on löess and clay tiles, with loose and sandy texture, with pH 6.3-6.9, index N 3.21, mobile phosphorus content 47-75 (ppm) and mobile potassium content 175-500 (ppm).

The active thermal balance $\left(\Sigma \mathrm{t}^{\circ} \mathrm{a}\right)$ is provided by the sum of average daily temperature grades, which exceeds the biological limit characteristic to the apricot tree, considered to be $6.5^{\circ} \mathrm{C}$ (Istrate, 2007).

$$
\Sigma \mathrm{t}^{\circ} \mathrm{a}=\Sigma \mathrm{T} \text { atd }-\mathrm{BL}, \text { in which: }
$$

$\Sigma \mathrm{T}$ atd $=$ sum of average temperature of days between two subsequent phenological stages;

$\mathrm{BL}=$ the biological limit of fruit tree species (Bordeianu et al., 1967).

We analyzed phenological aspects regarding data on buds swelling, buds burst, duration of bloom taken after BBCH scale for stone fruit. The bud swelling it's observed when bud scales elongated, with light coloured patches and corresponding to stage 51 on BBCH (Meier et al., 1994). First flowering was registered when $10 \%$ of flowers were open, corresponding to stage 61 on $\mathrm{BBCH}$. We also determined the trunk section area (TSA, in $\mathrm{cm}^{2}$ ) to calculate the trunk growth in section and determine the vigor of the varieties and we did analysis of fruit quality determined by the fruit weight.

The data obtained were statistically processed by variance analysis.

\section{RESULTS AND DISCUSSIONS}

In table 1 are presented data from three years, regarding the number of days from bud swelling to the beginning of flowering and the sum of active temperatures, above the biological threshold of $6.5^{\circ} \mathrm{C}$ needed for apricot (Hoza, 2000). The number of days from bud swelling to the beginning of flowering ranged between 10 to 13.3 days as average 2016-2018 period at seven studied apricot cultivars into Romanian Northeastern area conditions (table 1). Moale and Asănică (2017) find similar results about number of days from bud swelling (51 BBCH stage) to the beginning of blooming (61 BBCH stage) for 'Fortuna', 'Goldrich' and 'Dacia' cultivars studied for 2012-2013 period but into Romanian South area conditions. However, other studies described phenological stages for apricot cultivars in different conditions but the threshold temperature was cited as $7^{\circ} \mathrm{C}$ (Pérez-Pastor et al., 2004; Ruiz et al., 2007). Anyway, Ruml et al (2010) find that the values of threshold temperature differs among cultivars more for harvest than bloom time.

Sum of temperature degrees above the biological threshold registered values between $103.6^{\circ} \mathrm{C}$ to $136.4^{\circ} \mathrm{C}$ as average for all studied three years, with maximum values $172.9^{\circ} \mathrm{C}$ in 2017 at 'Ovidiu' and minimum values $79.1^{\circ} \mathrm{C}$ in 2016 at 'Fortuna', 'Amiral', 'Goldrich', 'Traian' and also 'Dacia' (table 1). 
Current Trends in Natural Sciences

Vol. 10, Issue 20, pp. 141-146, 2021

https://doi.org/10.47068/ctns.2021.v10i20.019

Current Trends in Natural Sciences (on-line)

Table 1. Number of days and sum of the active temperature from swelling buds (51 BBCH stage) to the beginning of blooming (61 BBCH stage) of the studied apricot cultivars (2016-2018, RSFG Iași)

\begin{tabular}{|c|c|c|c|c|c|c|c|c|}
\hline \multirow[b]{3}{*}{ Cultivar } & \multicolumn{6}{|c|}{ Year } & \multirow{2}{*}{\multicolumn{2}{|c|}{ Average }} \\
\hline & \multicolumn{2}{|c|}{2016} & \multicolumn{2}{|c|}{2017} & \multicolumn{2}{|c|}{2018} & & \\
\hline & Nr. of days & $\underset{\text { temp. }\left({ }^{0} \mathbf{C}\right)}{\sum \text { active }}$ & Nr. of days & $\underset{\text { temp. }\left({ }^{\mathbf{C}} \mathbf{C}\right)}{\sum \text { active }}$ & $\begin{array}{l}\text { Nr. of } \\
\text { days }\end{array}$ & $\begin{array}{c}\sum \text { active } \\
\text { temp. } \\
\left({ }^{\circ} \mathrm{C}\right)\end{array}$ & $\begin{array}{c}\text { Nr. of } \\
\text { days }\end{array}$ & $\begin{array}{c}\sum \text { active } \\
\text { temp. } \\
\text { ('C) }\end{array}$ \\
\hline Mamaia & 11 & 94.1 & 14 & 159.9 & 11 & 124.8 & $12.0^{\text {ns }}$ & $126.3^{\mathrm{ns}}$ \\
\hline Ovidiu & 13 & 111.6 & 16 & 172.9 & 11 & 124.8 & $13.3^{\text {ns }}$ & $136.4^{\mathrm{ns}}$ \\
\hline Fortuna & 9 & 79.1 & 14 & 145.8 & 11 & 124.8 & $11.3^{\text {ns }}$ & $116.6^{\mathrm{ns}}$ \\
\hline Amiral & 9 & 79.1 & 15 & 158.1 & 11 & 124.8 & $11.7^{\text {ns }}$ & $120.7^{\mathrm{ns}}$ \\
\hline Goldrich & 9 & 79.1 & 11 & 118.9 & 11 & 124.8 & $10.3^{\text {ns }}$ & $107.6^{\mathrm{ns}}$ \\
\hline Traian & 9 & 79.1 & 10 & 106.8 & 11 & 124.8 & $10.0^{\text {ns }}$ & $103.6^{\mathrm{ns}}$ \\
\hline Dacia & 9 & 79.1 & 10 & 106.8 & 11 & 124.8 & $10.0^{\text {ns }}$ & $103.6^{\mathrm{ns}}$ \\
\hline \multirow[t]{4}{*}{ Average (control) } & 10 & - & 13 & - & 11 & - & 11.23 & - \\
\hline & & & & & & DL 5\% & 2.33 & 24.19 \\
\hline & & & & & & DL $1 \%$ & 3.22 & 33.54 \\
\hline & & & & & & DL $0.1 \%$ & 4.48 & 46.59 \\
\hline
\end{tabular}



Figure 1. Apricot cultivar 'Amiral' (original)

Through the statistical interpretation of the results and their ratio to the average, there were no significant differences within the seven experimental variants compared with the average as control (table 1). But, the greatest values of sum of temperature degrees above the biological threshold were registered at 'Amiral' (figure 1) with $120.7{ }^{\circ} \mathrm{C}$, 'Mamaia' (figure 2) with $126.3{ }^{\circ} \mathrm{C}$ and 'Ovidiu' with $136.4^{\circ} \mathrm{C}$. Sparks et al., 2000 shows that climate change affects the start of flowering but Darbyshire et al., 2012 show that every degree Celsius of temperature increased advancing phenological stages with 4 to 7 days. 


\section{Current Trends in Natural Sciences}

Vol. 10, Issue 20, pp. 141-146, 2021

https://doi.org/10.47068/ctns.2021.v10i20.019

Current Trends in Natural Sciences (on-line)

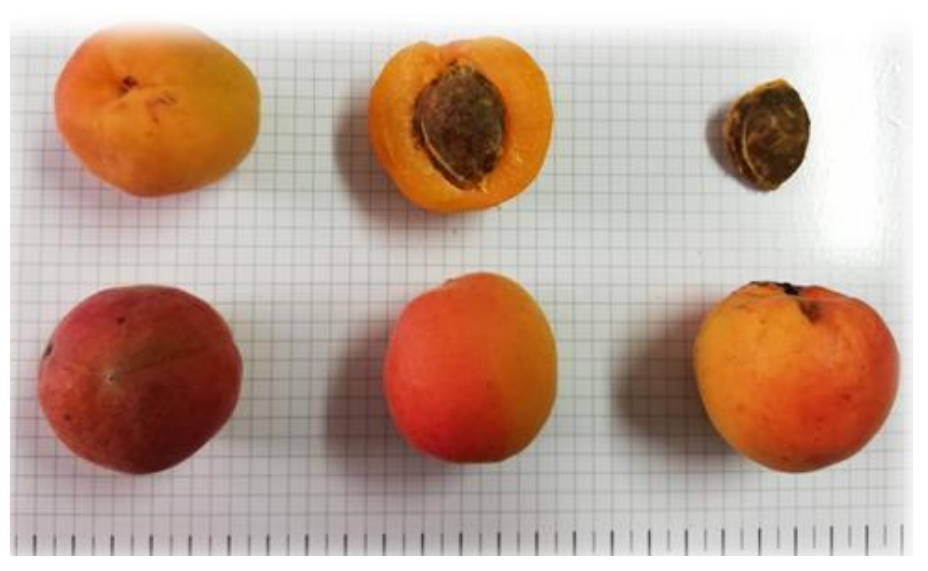

Figure 2. Apricot cultivar 'Mamaia' (original)

The vigor of trees were determined through the trunk's section area which were measured the trunk's thickness with the caliper and the data was converted in $\mathrm{cm}^{2}$ (Table 2).

Table 2. Trunk section area $\left(\mathrm{cm}^{2}\right)$ of the trees of the studied apricot cultivars (RSFG, 2016-2018)

\begin{tabular}{ccccc}
\hline Cultivar & $\mathbf{2 0 1 6}$ & $\mathbf{2 0 1 7}$ & $\mathbf{2 0 1 8}$ & $\begin{array}{c}\text { Average TSA } \\
\left(\mathbf{c m}^{\mathbf{2}}\right)\end{array}$ \\
\hline Traian & 109.2 & 119.4 & 125.3 & $118.0^{* * *}$ \\
Fortuna & 100.7 & 102.3 & 105.3 & $102.8^{* * *}$ \\
Dacia & 86.2 & 90.5 & 97.2 & $91.3^{* * *}$ \\
Amiral & 66.1 & 65.7 & 68.7 & $66.8^{\text {oo }}$ \\
Goldrich & 58.1 & 60 & 67.5 & $61.9^{\text {ooo }}$ \\
Mamaia & 40.1 & 43.4 & 45.4 & $43.0^{\text {ooo }}$ \\
Ovidiu & 22.9 & 24.1 & 32.5 & $26.5^{\text {ooo }}$ \\
\hline Average (control) & 69 & 72.2 & 77.4 & 72.8 \\
\hline
\end{tabular}

DL $5 \%=4.16 \mathrm{~cm}^{2} ;$ DL $1 \%=5.77 \mathrm{~cm}^{2} ;$ DL $0.1 \%=8.01 \mathrm{~cm}^{2}$

Regarding the vigor of the trees, the determinations showed very significant positive statistically differences for 'Traian', 'Fortuna' and 'Dacia' with $118.0 \mathrm{~cm}^{2}, 108.8 \mathrm{~cm}^{2}$ and respectively $91.3 \mathrm{~cm}^{2}$, while 'Goldrich', 'Mamaia' and 'Ovidiu' registered low vigor tree as 61.9 $\mathrm{cm}^{2}, 43.0 \mathrm{~cm}^{2}$ respectively $26.5 \mathrm{~cm}^{2}$ TSA with very significant negative statistically differences (table 2). In terms of vigor of the trees, low parameters give possibilities for high density plantations but the influences of the rootstock is also important (Missere et al., 2010).

In terms of fruit weight, the results showed differences between studied apricot cultivars and years taken into evaluation (table 3). Largest fruits registered 'Dacia' and 'Amiral' with $89.3 \mathrm{~g}$ and respectively $75.3 \mathrm{~g}$ fruit weight with very significant positive statistically differences than average as control (table 3). The lowest value of fruit weight we find at 'Traian' with $37 \mathrm{~g}$ in 2016, but the greatest value was at 'Dacia' with $95 \mathrm{~g}$ in 2018. 
Current Trends in Natural Sciences

Vol. 10, Issue 20, pp. 141-146, 2021

https://doi.org/10.47068/ctns.2021.v10i20.019

Current Trends in Natural Sciences (on-line)

Table 3. The fruit's weight of the studied apricot cultivars (RSFG Iasi, 2016-2018)

\begin{tabular}{ccccc}
\hline & \multicolumn{3}{c}{ Fruit weight (g) } & \multirow{2}{*}{$\begin{array}{c}\text { Average weight of the } \\
\text { fruit (g) }\end{array}$} \\
\cline { 2 - 4 } & $\mathbf{2 0 1 6}$ & $\mathbf{2 0 1 7}$ & $\mathbf{2 0 1 8}$ & \\
\hline Dacia & 85 & 88 & 95 & $89.3^{* * * *}$ \\
Amiral & 71 & 75 & 80 & $75.3^{* * *}$ \\
Ovidiu & 66 & 68 & 72 & $68.7^{*}$ \\
Goldrich & 51 & 55 & 61 & $55.7^{\circ}$ \\
Mamaia & 47 & 52 & 58 & $52.3^{\circ 00}$ \\
Fortuna & 40 & 51 & 58 & $49.7^{\circ 00}$ \\
Traian & 37 & 42 & 43 & $40.7^{\circ 00}$ \\
\hline Average (control) & 57 & 62 & 67 & 62 \\
\hline DL 5\%=3.59 g; DL 1\%=4.98 g; DL 0.1\%=6.91 g. & & & \\
\hline
\end{tabular}

Egea et al., 2010 find in Spain similar results at new nine apricot cultivars in which fruit weight ranged between 51 to $92 \mathrm{~g}$.

\section{CONCLUSIONS}

In the different climatic conditions, we notice that the apricot cultivars need different number of days from the swelling of the buds to the blooming. Values of the sum of active temperature varied according to the climatic conditions year by year at different cultivar. Regarding of the trees vigor 'Mamaia' and 'Ovidiu' are apricot cultivars more suitable for high density plantation. Regarding the weight of the fruits 'Dacia' and 'Amiral' are suitable apricot cultivars for fresh consumption.

\section{ACKNOWLEDGEMENTS}

This work was financially supported by the Romanian Academy of Agricultural and Forestry Sciences, Grant No. ASAS 1 - 1.4., with title 'Zonation and microzonation of varieties and rootstocks of fruit tree species'.

\section{REFERENCES}

Bălan V. (2008). Caisul și caisele [Apricot Tree Species and Apricots]. Ed. Ceres, București.

Berar V. (2002). Horticultura [Horticulture]. Ed. de Vest, Timișoara.

Bordeianu T., Constantinescu N., Ștefan N. (1967). Pomologia Republicii Socialiste Romania. Cap. V. Caisul Piersicul [Pomology of the Socialist Republic of Romania. In Chapter V. Apricot - Peach]. Ed. Ceres, București.

Militaru M. (coord.), Coman M., Butac M., Sturzeanu M., Titirică I., Călinescu M., Stanciu C., Botu M., Gavăt C., Sîrbu S., Iurea E., Erculescu M., Sestraș A. (2015). Fondul de germoplasmă la speciile pomicole cultivate în România [Germplasm fund for fruit species cultivated in Romania]. Ed. Invel Multimedia, Piteşti.

Moale C., Asănică A. (2017). The Effect of Certain Climatic Parameters on the Apricot Tree. Scientific Papers. Series $B$, Horticulture. LXI, 69-79.

Cociu V. (1993). Caisul [Apricot tree]. Ed. Ceres, Bucuresti.

Cociu V. (1990). Soiurile noi, factor de progres în agricultură [New varieties, a factor of progress in agriculture]. Ed. Ceres, Bucureşti.

Corneanu G., Corneanu M. (2003). Sfaturi pomicole [Fruit Tree Growing Advices]. Ed. PIM Iaşi.

Darbyshire R., Webb L., Goodwin I., Barlow E. W. R. (2012). Evaluation of recent trends in Australian pome fruit spring phenology. Int. J. Biometeorol. 57 (3), 409-421. 


\section{Current Trends in Natural Sciences}

Vol. 10, Issue 20, pp. 141-146, 2021

https://doi.org/10.47068/ctns.2021.v10i20.019

Current Trends in Natural Sciences (on-line)

ISSN: 2284-953X

Current Trends in Natural Sciences (CD-Rom)

ISSN: 2284-9521

ISSN-L: 2284-9521

ISSN-L: 2284-9521

Egea J., Dicenta F., Burgos L., Martínez-Gómez P., Rubio M., Campoy J.A., Ortega E., Patiño J.L., Nortes L., Molina A. , Ruiz D. (2010). New Apricot Cultivars from CEBAS-CSIC (Murcia, Spain) Breeding Programme, Proc. XIV ISHS on Apricot Breeding and Culture. Ed. C. Xiloyannis. Acta Hort. 862, 113-118.

Faostat. (2020). http://www.fao.org/faostat/en/\#data/QC, 08.10.2020

Grădinariu G. (2002). Pomicultură specială [Special Fruit Tree Growing]. Ed. I. I. de la Brad, Iaşi.

Hoza D. (2000). Pomologie [Pomology]. Ed. Prahova, Ploiești.

Istrate M. (2007). Pomicultură generală [General Fruit Growing]. Ed. I. I. de la Brad, Iaşi.

Meier U. (2001). Growth stages of mono-and dicotyledonous plants - BBCH Monograph. The BBCH codes are on homepage of the Julius Kühn-Institute (JKI): http://www.jki.bund.de.

Missere D., Mezzetti B., Capocasa F., Scalas B., Podda A., Pirazzini P., Sottile F., Pennone F., Carbone A., Scarpato L. (2010). New Low-Vigour Apricot Rootstocks Compared. Acta Hort. 862, 295-300. DOI: 10.17660/ActaHortic.2010.862.45

Pérez-Pastor A., Ruiz-Sánchez M. C., Domingo R., Torrecillas A. (2004). Growth and phenological stages of Búlida apricot trees in south-east Spain. Agronomie 24, 93-100. DOI: 10.1051/agro:2004004.

Ruiz D., Campoy J. A., Egea J. (2007). Chilling and heat requirements of apricot cultivars for flowering. Environmental and Experimental Botany 61 (3), 254-263. DOI: 10.1016/j.envexpbot.2007.06.008.

Ruml M., Vuković A., Milatović D. (2010). Evaluation of different methods for determining growing degree-day thresholds in apricot cultivars. Int J Biometeorol 54, 411-422. DOI 10.1007/s00484-009-0292-6.

Sîrbu C., Paraschiv N.L. (2005). Botanică sistematică [Systematic Botany]. Ed. I. I. de la Brad. Iaşi.

Sparks T.H., Jeffree E.P., Jeffree C.E. (2000). An examination of the relationship between flowering times and temperature at the national scale using long-term phenological records from the UK. International Journal of Biometeorology 44, 82-87. 